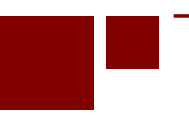

C E N T E R for RETIREMENT RES E A R C H at BOSTON COLLEGE

\title{
HOW MUCH INCOME DO RETIREES ACTUALLY HAVE? EVALUATING THE EVIDENCE FROM FIVE NATIONAL DATASETS
}

\author{
Anqi Chen, Alicia H. Munnell, and Geoffrey T. Sanzenbacher
}

CRR WP 2018-14

November 2018
Center for Retirement Research at Boston College
Hovey House
140 Commonwealth Avenue
Chestnut Hill, MA 02467

Tel: 617-552-1762 Fax: 617-552-0191

http://crr.bc.edu

All authors are with the Center for Retirement Research at Boston College. Anqi Chen is the assistant director of savings research, Alicia H. Munnell is the director, and Geoffrey T.

Sanzenbacher is the associate director of research. The research reported herein was performed pursuant to a grant from the U.S. Social Security Administration (SSA) funded as part of the Retirement Research Consortium. The opinions and conclusions expressed are solely those of the authors and do not represent the opinions or policy of SSA, any agency of the federal government, or Boston College. Neither the United States Government nor any agency thereof, nor any of their employees, makes any warranty, express or implied, or assumes any legal liability or responsibility for the accuracy, completeness, or usefulness of the contents of this report. Reference herein to any specific commercial product, process or service by trade name, trademark, manufacturer, or otherwise does not necessarily constitute or imply endorsement, recommendation or favoring by the United States Government or any agency thereof. The authors thank Melanie Qing for excellent research assistance.

(c) 2018, Anqi Chen, Alicia H. Munnell, and Geoffrey T. Sanzenbacher. All rights reserved. Short sections of text, not to exceed two paragraphs, may be quoted without explicit permission provided that full credit, including $(\mathcal{C}$ notice, is given to the source. 


\begin{abstract}
About the Center for Retirement Research
The Center for Retirement Research at Boston College, part of a consortium that includes parallel centers at the University of Michigan and the National Bureau of Economic Research, was established in 1998 through a grant from the Social Security Administration. The Center's mission is to produce first-class research and forge a strong link between the academic community and decision-makers in the public and private sectors around an issue of critical importance to the nation's future. To achieve this mission, the Center sponsors a wide variety of research projects, transmits new findings to a broad audience, trains new scholars, and broadens access to valuable data sources.
\end{abstract}

Center for Retirement Research at Boston College

Hovey House

140 Commonwealth Ave

Chestnut Hill, MA 02467

Tel: 617-552-1762 Fax: 617-552-0191

http://crr.bc.edu

Affiliated Institutions:

The Brookings Institution

Syracuse University

Urban Institute 


\begin{abstract}
Recent research by Bee and Mitchell (2017) has refocused attention on the fact that the Current Population Survey (CPS) underestimates retirement income. In the wake of this study, some observers have questioned whether other surveys more frequently used by retirement researchers also understate retirement income and, if so, whether prior research suggesting that many households are unprepared for retirement is accurate. This paper addresses both questions by examining retirement income data from the CPS and four other surveys: 1) the Survey of Consumer Finances (SCF); 2) the Health and Retirement Study (HRS); 3) the Panel Survey of Income Dynamics (PSID); and 4) the Survey of Income and Program Participation (SIPP). The paper compares the income measures from each survey to administrative data from tax and Social Security records, both in aggregate and across the income distribution. It then uses a common measure of retirement income adequacy, the replacement rate, to assess overall household preparedness for retirement.

The paper found that:
\end{abstract}

- The SCF, HRS, and SIPP capture nearly 100 percent, 96 percent, and 93 percent of retirement income from administrative data, respectively, and provide largely consistent estimates across the income distribution.

- The PSID captures over 80 percent of income from administrative data, with most of the underreporting occurring at the top of the income distribution.

- The CPS is an outlier in terms of its ability to measure retirement income relative to administrative data, capturing just 61 percent. This underreporting exists at all points in the income distribution.

- The estimates of median replacement rates vary from 55 to 91 percent, depending on the definition of pre-retirement income. Using a target replacement rate of 75 percent, these estimates imply that between 42 and 60 percent of households are at risk of falling short. The policy implications of the findings are:

- Research based on these datasets provides an accurate depiction of retirement income in the middle of the income distribution, while the SCF, HRS, and SIPP are accurate throughout the distribution.

- Estimates from these data indicate many households are still in danger of not having enough resources in retirement. 


\section{Introduction}

Recent research by Bee and Mitchell (2017) has refocused attention on the fact that the Current Population Survey (CPS) underestimates the income of retirees when compared to administrative tax data from the Internal Revenue Service (IRS) and the Social Security Administration (SSA). Some observers assume that these results apply to retirement income measures in survey data generally, and have called into question prior research suggesting that a large proportion of the population is not financially prepared for retirement. The question is whether other datasets frequently used by researchers underestimate retirement income and, if so, by how much and where in the distribution?

To address this question, this paper evaluates four datasets used for estimating retirement income: 1) the Survey of Consumer Finances (SCF); 2) the Health and Retirement Study (HRS); 3) the Panel Survey of Income Dynamics (PSID); and 4) the Survey of Income and Program Participation (SIPP). The CPS is included in the analysis as well. The procedure is to calculate retirement income for each of the five datasets and compare the measures to administrative data, using the most recent versions of those surveys available. This exercise is important, since whether households have enough income in retirement informs evaluations of the adequacy of the private retirement system and discussions on Social Security reform.

The results suggest that the other datasets provide estimates that track much more closely with administrative data than the CPS. At the aggregate level, the SCF, HRS, and the SIPP capture nearly 100 percent, 96 percent, and 93 percent of retirement income, respectively. The PSID captures somewhat less, accounting for about 81 percent of aggregate retirement income. However, this finding masks the underlying agreement at the median of the income distribution, where the SCF, HRS, SIPP, and PSID all track closely with administrative data. The lower aggregate estimates from the PSID are due mainly to the understatement of retirement income at the top of the income distribution. The CPS is an outlier, lagging behind the other four datasets. Even after a recent redesign - which was meant to improve income measurements - the CPS only captures about 60 percent of aggregate retirement income and also falls below the other datasets at the middle of the distribution.

Given that four of the datasets track closely to administrative data, a natural question is whether the income amounts are enough for a secure retirement. To this end, the paper puts these estimates into context using the replacement rate - the ratio of post-retirement income to 
pre-retirement income - as an indicator of retirement income adequacy. The HRS is chosen to calculate these replacement rates, since it includes both: 1) an accurate assessment of postretirement income; and 2) longitudinal earnings records to calculate pre-retirement income. The finding is that median replacement rates vary from 55 to 91 percent, depending on how preretirement income is defined. Using a commonly cited replacement rate target of 75 percent, the estimates imply that 42 to 60 percent of households are at risk of falling short.

The rest of the paper is organized as follows. The second section describes the survey design and income definitions of the five datasets used in this paper. The third section provides a review of the literature on estimates of retirement income from these datasets. The fourth section presents the results, comparing retirement income from each dataset with administrative data, both in aggregate and across the income distribution. The fifth section presents the results in the context of replacement rates. The final section concludes that while recent research suggests that older households may have a lot more income than is captured in survey data, those results are unique to the CPS. Other survey data provide income estimates that are more consistent with the administrative data, and still suggest that about half of households face a retirement shortfall.

\section{Data}

The analysis uses data from the most recent survey year available for five nationally representative datasets: 1) the 2017 March Supplement of the CPS; 2) the 2016 SCF; 3) the 2016 early release from the HRS, linked with earnings records; 4) the 2014 PSID; and 5) the 2014 panel of the SIPP. The following discussion provides more specifics on each dataset.

\section{Current Population Survey}

The CPS was originally designed to measure the monthly unemployment rate for the civilian non-institutionalized population. In addition to labor force statistics, however, it also conducts supplements meant to capture more information on a household's economic situation. Perhaps the most often cited of these, the March Supplement (more formally, The Annual Social and Economic Supplement), contains information on the amount and sources of income from the previous calendar year and is the official government source for poverty statistics. The analysis in this paper uses the 2017 March Supplement, which surveyed approximately 75,000 households about their income receipts in the prior calendar year. 
The CPS defines income as money received on a regular basis, excluding capital gains. Prior studies have found that the CPS understates the resources households have access to in retirement. ${ }^{1}$ One reason is that - unlike defined benefit (DB) plans - defined contribution (DC) plans, such as 401(k)s and IRAs, accrue account balances and generally do not pay out regular income streams. ${ }^{2}$ In response to researcher concerns, the Census redesigned the 2015 CPS, adding and re-ordering questions to better assess sources of income for older and lower-income households. In particular, questions were added explicitly on withdrawals from all 401(k), 403(b), and IRA accounts - in the past, the survey only mentioned "pensions or retirement income" broadly. ${ }^{3}$ However, respondents are still primed with questions about the frequency of these withdrawals (i.e. whether payments are received weekly, monthly, quarterly, or annually), likely limiting responses for one-time or irregular distributions. Interestingly, Bee and Mitchell (2017), which uses data prior to the redesign, found that the CPS understates DB as well as DC income. This paper uses the redesigned CPS, so it will provide insight into how the redesigned questions compare with other surveys.

\section{Survey of Consumer Finances}

The SCF is a triennial survey designed to capture detailed information on the financial accounts of U.S. households. The most recent SCF, conducted in 2016, surveys approximately 6,000 households and provides comprehensive information on their assets and debts, income amounts and sources, investments, pensions, spending, and their interactions with credit markets. It is often considered the "gold standard" for data on household income and wealth. ${ }^{4}$

The SCF asks respondents about eight distinct sources of retirement income: Social Security and Railroad Retirement benefits, DB pensions, disability pensions, retirement account withdrawals, IRA withdrawals, annuities, pre-retirement withdrawals, and lump-sum settlements and distributions. In contrast with the CPS, both regular income and irregular income are

\footnotetext{
${ }^{1}$ See Fisher (2008); Davies and Fisher (2009); Iams and Purcell (2013); and Munnell and Chen (2014) for more analysis.

${ }^{2}$ The paper uses $401(\mathrm{k}) \mathrm{s} / \mathrm{IRAs}$ to describe all defined contribution retirement accounts.

${ }^{3}$ Additional questions in the redesign distinguish whether the withdrawals were rolled over or reinvested. Other features of the redesign include: individual questions to identify each income source; separate questions on the amount from each source; and question re-ordering based on income level and age to minimize misreporting and the effect of respondent fatigue. Follow-up questions were also added when these income questions were unanswered.

${ }^{4}$ See the literature review for examples of studies that find the SCF performs well when compared to administrative data, both in terms of income and wealth.
} 
captured since respondents are allowed to answer "no regular payment" or "varies" when asked about the frequency of payments or withdrawals. The design of the SCF also lends itself to capturing a complete picture of the income distribution because, in addition to extensive questions, it also purposefully oversamples higher-wealth households. While these individuals generally have lower response rates and thus may be excluded completely from other surveys, they own a relatively large share of aggregate net worth. The SCF does have a number of disadvantages relative to other surveys: it is only conducted once every three years, is a crosssectional dataset instead of a panel, and surveys a relatively small sample of households and thus ends up with a small sample of workers near retirement.

\section{Health and Retirement Study}

The HRS is a panel survey of households in which the head is age 51 or older. This survey has been administered every two years since 1992. Initially, the sample consisted of individuals born between 1931 and 1941, but every six years a new (younger) cohort is added to the data.

The goal of the HRS is to examine how health, economic, social, and psychological factors interact to influence outcomes just prior to and in retirement. The survey collects indepth information on income, work histories, assets, pensions, health insurance, disability, physical health and functioning, cognitive function, and health care expenditures. This paper uses version 2 of the 2016 early release from the HRS linked with Social Security administrative earnings histories. ${ }^{5}$ Similar to the SCF, the HRS allows respondents to record one-time payments and asks extensive questions about different sources of income. Additionally, in 2012, the HRS revalidated prior information provided on retirement plans for each respondent. The HRS design helps ensure more accurate responses and captures both regular income from retirement plans and annuities and occasional or non-recurring withdrawals.

\footnotetext{
${ }^{5}$ The 2016 early release did not include the younger cohort of households that were due to be added. Since the analysis in this paper focuses on households ages $65+$, they would already be included in the existing panel survey participants. The 2016 early release contains about 97 percent of the panel participants, so results would not vary much with the final release.
} 


\section{Panel Study of Income Dynamics}

The PSID is a household panel survey that has followed a nationally representative sample of over 5,000 initial families since 1968. The PSID follows both the initial respondents and their descendants, thereby providing valuable information on the long-run dynamics of income, wealth, employment, and family structure of the original respondents across generations.

This paper uses the 2014 panel of the PSID which has now grown to over 9,000 families. Unlike the SCF and HRS, the PSID does not contain a specific question on withdrawals from 401(k)s/IRAs. Rather it asks about the amount received from retirement pay, annuities, or pensions. ${ }^{6}$ The line of questioning in the PSID also differs considerably from all of the datasets discussed above, in that it does not specify that respondents include irregular or non-recurring income payments nor does it explicitly exclude them, like the CPS. It simply asks how much in total was received in the calendar year.

\section{Survey of Income and Program Participation}

The main objective of the SIPP is to evaluate the eligibility of households for federal, state, and local programs and their use of these programs. Because many government programs have both income and asset tests, the SIPP provides detailed data on cash and non-cash income, taxes paid, and information on assets and debts. ${ }^{7}$ This paper uses wave 2 of the 2014 redesigned SIPP, which interviews over 12,000 households. Prior to the redesign, the SIPP interviewed individuals every four months for roughly two to five years. Some information, such as the amount of income from labor, was collected through a "Core Questionnaire" every four months. Other information, such as retirement income and assets, was only collected through specific “Topical Modules." To reduce administrative and respondent burden, the 2014 SIPP changed this structure and now collects data annually through a single questionnaire. A sample of SIPP respondents are then surveyed again about their retirement plan participation, contributions, and withdrawals, among other questions. This redesign focused on the structure of the survey, and retirement income questions remained unchanged. While past studies have suggested SIPP

\footnotetext{
${ }^{6}$ The PSID asks about the source and amount of income separately: "Not including Veteran's Administration pensions, how many different pensions, IRAs or annuities did [you / [HEAD]] receive income from in 2010?" and "How much was it?"

${ }^{7}$ The SIPP also asks about the amount from each source separately: "How much did ... withdraw from 401k, 403b, or thrift plan accounts during 2010?", and "How much did ... withdraw from IRA accounts during 2010?"
} 
estimates of post-retirement income are lower than in other data, this paper will provide an early look at the redesigned data. ${ }^{8}$

These five datasets represent some of the most commonly used data in research related to retirement income. The question is how they compare to each other and to aggregate numbers from administrative data.

\section{Literature}

Although no previous study has undertaken a comprehensive comparison of retirement income in these five datasets, it has been well documented that the CPS underreports retirement income relative to other sources (Schieber, 1995; Woods, 1996; Czajka and Denmead, 2008; Fisher, 2008; Davies and Fisher, 2009; Iams and Purcell, 2013; Munnell and Chen, 2014; and Miller and Schieber, 2014). Bee and Mitchell (2017) has refocused attention on this underreporting; linking the 2012 CPS to administrative records from the IRS and SSA, the paper came to a similar conclusion as the earlier literature - the CPS understates median retirement income by 30 percent relative to administrative data for households ages 65 and over in 2012 .

The accuracy of retirement income measurements across other datasets has not been studied as comprehensively as it has in the CPS. Still, a few papers provide an important foundation for the analysis undertaken in this paper. The most comprehensive are Czajka and Denmead (2008 and 2012), which compare income data from a total of nine different datasets. The results show that the aggregate income from the SIPP and CPS lags behind those from the SCF, HRS, and PSID. Retirement income, however, was not the focus of the reports, and the datasets were not all benchmarked against administrative data.

Studies that compared retirement income to administrative data have found somewhat more positive results. For example, Dushi, Iams and Trenkamp (2017) linked the CPS, SIPP, and HRS to Social Security earnings records and found that the percentage of households relying on Social Security for the majority of their income was comparable across the datasets. However, this study did not include estimates of retirement plans, an important source of income for older households. Gustman, Steinmeier, and Tabatabai (2010) and Dettling et al. (2015) considered a more comprehensive measure of retirement income in the HRS and SCF,

\footnotetext{
${ }^{8}$ Czajka and Denmead (2008).
} 
respectively. ${ }^{9}$ Their findings showed that both datasets compared favorably to administrative aggregates. The limitation is that these papers focused on one survey dataset and did not explore how well these datasets performed across the income distribution. Although the focus of this paper is retirement income, the wealth available to generate that income has also been the subject of other research. For example, Bosworth and Smart (2009) compared estimates from the SCF, HRS, and PSID and found that all three datasets are comparable for the bottom 95 percent of the income distribution, but the SCF provides higher estimates for the top 5 percent of households.

This study builds on the existing literature by providing a comprehensive comparison of retirement income measurements - both in aggregate and across the distribution - for five different datasets and an initial appraisal of the CPS and SIPP redesigns. The analysis also fills an important space in the literature, presenting a cross-survey analysis of how different sources of retirement income compare with administrative data.

\section{Results}

This section presents results, first for aggregate income and then for different points in the income distribution. Aggregate income from each dataset is compared, by source, with administrative records from the IRS SOI 1040 forms and Social Security's Annual Statistical Supplement. This exercise shows how well each dataset captures the income of older households at the national level. Aggregates are estimated for each survey by multiplying self-reported income with their representative weights and then adding up the resulting numbers. In addition, for each dataset, the sample is divided into five quintiles of total income and compared to quintile averages for the administrative data. ${ }^{10}$ The sample used in this paper consists of households, both couples and singles, ages 65 and older. ${ }^{11}$

\footnotetext{
${ }^{9}$ Gustman, Steinmeier, and Tabatabai (2010) linked HRS self-reported responses of retirement income with administrative records from employers and found that, although respondents misreported income, the amount of underreporting and overreporting was similar so that, on average, the HRS provided reasonable estimates.

10 Total income in this analysis is defined as the sum of wage and salary income; employer-sponsored retirement plans - both regular payments and irregular withdrawals; Social Security income; business and farm income; income from interest and dividends; and Supplemental Security Income. Capital gains (losses) and proceeds from the sale of businesses or property are not considered income.

${ }^{11}$ If other members of the household or family are surveyed, their responses are ignored.
} 


\section{Aggregate Income}

The first step is to compare aggregates across datasets with the IRS and SSA administrative data for the three major types of income in retirement: 1) retirement plans (DB, DC, and IRA); 2) Social Security; and 3) interest and dividends. ${ }^{12}$ The IRS data are used for retirement plans and interest and dividends, while SSA data are used for Social Security benefits. The analysis compares the CPS, SCF, and HRS to administrative data from 2016, and the PSID and SIPP to data from 2014. All results are presented in 2016 dollars.

Table 1 shows that the SCF tracks closest to administrative data, accounting for 98 percent of retirement income reported by the IRS. The HRS and SIPP also provides reliable estimates, accounting for 96 percent and 93 percent of administrative aggregates. The one area that these two datasets underreport is interest and dividends income, where the HRS accounts for 88 percent and the SIPP accounts for 60 percent of administrative aggregates. Because interest and dividends represent only a small share of total retirement income, the effect on the aggregate comparison is relatively modest. As expected, the CPS severely underreports income from retirement plans and thus overall income, an issue the redesign does not seem to have corrected. ${ }^{13}$ This finding is consistent with Bee and Mitchell (2017) and much of the other literature conducted before the redesign. One result of note is that the redesigned SIPP provides much more accurate aggregate estimates, while the Czajka and Denmead (2008) study mentioned above had found performance of the original SIPP more similar to the CPS. ${ }^{14}$

The table also shows that the PSID falls somewhat short of the administrative data, but provides higher estimates than the CPS, tracking administrative aggregates at a rate of 81 percent. Similar to the HRS, underreporting in the PSID is most pronounced for the interest and dividend income category. This result is no surprise, because the overwhelming majority of interest and dividend income is earned by very high-income households and the HRS, PSID, and SIPP do not oversample these individuals, potentially leaving them out of the sample entirely an issue weighting cannot fix.

\footnotetext{
${ }^{12}$ Some households over age 65 may have earnings, but in general the data cited in this paper provide similar estimates of earnings.

${ }^{13}$ Retirement plans, for the purposes of this study, include employer-sponsored defined benefit and defined contribution plans, IRAs, and annuities.

14 This finding is consistent with Eggleston and Gideon (2017), which found that estimates of wealth in the redesigned SIPP were higher compared to the SCF even though the questions in the redesigned SIPP did not change significantly.
} 
In any case, the aggregate results suggest that, relative to the CPS, retirement income estimates from these national surveys do a decent job tracking with administrative data. Given that aggregates can mask underlying discrepancies, it is important to understand where in the distribution these shortfalls occur. If, for example, differences across datasets are mainly due to the fact that very high-income households are not represented, then income measurements should be relatively consistent across datasets in the middle and lower quintiles of the distribution.

\section{Distribution of Income}

This exercise involves comparing average retirement income from Social Security and retirement plans - the two main sources of retirement income for the vast majority of households - by quintile with administrative data. Since the IRS and SSA do not publish data for older households by income group, the analysis updates income measurements by quintile from administrative records for 2012, as presented in Bee and Mitchell (2017). ${ }^{15}$ This estimate is accomplished by adjusting income from each source by its respective growth between 2012 and 2016 (CPS, SCF, and HRS) or between 2012 and 2014 (PSID and SIPP) among households ages 65 and older. The assumption is that income from Social Security and retirement plans grew at the same rate across the income distribution.

Figures 1a and $1 \mathrm{~b}$ compare Social Security income from the administrative data to each of the five datasets. The results show that Social Security income for all the datasets, except the CPS, aligns closely at each quintile across the distribution. The CPS, on the other hand, understates Social Security income at all points in the income distribution. For these households, the CPS understates income from Social Security by about 20 percent.

Estimates of income from retirement plans across datasets show the same pattern described in the aggregate section. The SCF, HRS, and SIPP provide estimates that are largely consistent with administrative data at all points in the income distribution (see Figure $2 \mathrm{a}$ ). The PSID provide reliable estimates of income from retirement plans for the bottom 80 percent of households. For older households in the highest quintile, the PSID and SIPP underestimate income from retirement plans by 31 percent (see Figure 2b). The CPS substantially understates income from retirement plans for all households across the income distribution (see Figure 2a).

\footnotetext{
${ }^{15}$ Only the sources of income that were linked to administrative records in Bee and Mitchell (2017) were included in total income. Households are sorted into income quintiles by total income. This was to provide better apples-toapples comparisons between different surveys and administrative aggregates.
} 
Even at the median, the gap between CPS and administrative estimates of retirement income is 59 percent.

The takeaway is that, once again, the CPS is an outlier. All other datasets - the SCF, HRS, PSID, and SIPP - provide reliable estimates of retirement income from Social Security and retirement plans for the bottom 80 percent of the income distribution. The SCF and the HRS provide income measurements consistent with administrative data, even for top-quintile households.

One issue with measuring retirement income is that the shift from DB to DC wealth means income observed at a point in time may not reflect the long-term income available to a household - distributions from 401(k)/IRA accounts may not accurately reflect how much money households have available in retirement. Households may withdraw too much and thus may run out of wealth before they die or, alternatively, withdraw very little and maintain a substantial nest egg. One way to get around this issue, as seen in the literature, is to look instead at "potential income" or the amount of income that could be generated from retirement wealth.

\section{Potential Income}

The analysis calculates potential income by assuming that each household uses the total amount of 401(k)/IRA wealth to purchase inflation-adjusted annuities. Converting 401(k)/IRA wealth into a stream of payments shows the potential of DC plans to generate income in retirement in contrast to using the actual amount withdrawn. ${ }^{16}$ Figure 3 compares actual income to potential income from retirement plans (the CPS is not shown because it does not contain data on wealth).

The results show that, for most households, annual withdrawals from their 401(k)/IRA plans are fairly close to what an inflation-adjusted annuity would provide. That is, current income and potential income are measuring roughly the same thing. Households in the highest quintile, on the other hand, have far more potential income. That is, since top-quintile households withdraw less than their potential income, even administrative data will underestimate how much income households at the top of the income distribution have access to in retirement.

\footnotetext{
${ }^{16}$ Annuity Prices are obtained from ImmediateAnnuities.com. Prices are as of July 9, 2018. Couples are assumed to purchase a joint-survivor annuity.
} 


\section{Will Retirees Have Enough Income?}

The evidence thus far shows that retirement income estimates from four commonly used surveys - the SCF, HRS, PSID, and SIPP - are largely consistent with administrative data, especially in the middle of the income distribution. However, the level of income does not provide any indication as to whether older households can maintain the same standard of living in retirement as they had in their working years. To determine whether income is adequate, it is useful to examine a common measure of whether households have enough financial resources in retirement: the replacement rate - a ratio of post-retirement income to pre-retirement income. ${ }^{17}$

\section{Replacement Rates}

The numerator of the replacement rate, post-retirement income, comes from the HRS. In addition to performing well relative to administrative data, the HRS has a unique benefit of being a panel dataset that can be merged with administrative earnings records, an important feature for calculating the denominator in this exercise. The denominator for the replacement rate, preretirement income, can be defined in many different ways, and conclusions on adequacy are sensitive to the definition of pre-retirement income. ${ }^{18}$ Two key dimensions of the definition include: 1) the length of the earnings period considered (e.g., late-career versus career-average); and 2) the method for indexing earnings (e.g., price growth versus economy-wide earnings growth). Because the academic literature does not agree on which is most appropriate, the paper estimates replacement rates under four definitions that vary along these dimensions. The results, presented in Figure 4, are described below.

Last Year of Earnings. Retirement income is sometimes compared to earnings in the last year before retirement to provide a sense of how retirement income compares to late-career earnings. Measuring retirement income relative to late-career earnings can provide a comparison of workers' standard of living near retirement, rather than earlier on in their careers. Final-year earnings, however, is a poor proxy even for late-career earnings since this measurement can be volatile and misleading, especially for households that may no longer be working in the year

\footnotetext{
${ }^{17}$ The percentage of pre-retirement income needed to maintain the same standard of living in retirement can vary for different households. For example, lower-income households will typically need a higher replacement rate because they spend a higher portion of their income on necessities and will not expect a significant decline in expenditure from taxes and savings.

${ }^{18}$ See Fox (1979 and 1982); Mitchell and Phillips (2006); Munnell and Soto (2005); Springstead and Biggs (2008); and Goss et al. (2014) for examples.
} 
before they claim Social Security. ${ }^{19}$ Using final-year earnings provides median replacement rates that are over 90 percent. This high replacement rate is unsurprising, given that the final year of earnings is likely to be lower than a typical year. ${ }^{20}$

Last 5-years of Earnings, Excluding Zeros. The last 5 years of significant non-zero earnings smooths some of the volatility in final-year earnings and likely provides a better measure of late-career earnings than simply the last year. ${ }^{21}$ Nonetheless, this measure still may not accurately reflect late-career earnings, since many may reduce their labor market participation by shifting to part-time or lower paying work as they transition into retirement. This measure also has the potential to overstate lifetime income for those who hit peak earnings right before retirement. This definition produces a median replacement rate of 55 percent.

Highest 35-Year Earnings - CPI Indexed. One measure of pre-retirement income that avoids potentially volatile income measures just before retirement is indexing career average earnings to the CPI. Specifically, the price indexed career-average earnings measure is often defined as the average of the highest 35 years of taxable earnings, indexed to price growth. This measure allows earnings to keep up with inflation. Under this definition of pre-retirement income, the median replacement rate is about 72 percent. However, price-indexed earnings do not account for productivity gains achieved during a household's working career, which means they understate actual wage growth. Thus, indexing career-average earnings to prices would not allow households to maintain the standard of living they achieved at the end of their careers.

Highest 35-Year Earnings - AWI Indexed. Similar to the above measure, average-wage indexed (AWI) career-average earnings is also the average of the highest 35 years of taxable earnings. However, earnings are instead indexed to economy-wide wage growth. This measure allows earnings to adjust to rising standards of living over time and shows that the median household over the age of 65 has a replacement rate of 63 percent. As the standard of living rises over time, using average-wage indexed earnings allows households to maintain the standard of living at the end of their careers. This definition is also the one used by the OECD to compare Social Security and pension benefits across countries.

\footnotetext{
${ }^{19}$ Biggs and Springstead (2008) and Goss et al. (2014).

20 This finding is consistent with those from Brady et al. (2017), which also used final-year earnings.

${ }^{21}$ Significant earnings is defined as annual earnings greater than $\$ 100$. This definition is consistent with that used in Goss et al. (2014).
} 
To give these replacement rates a bit more context, a general rule-of-thumb is that households should target a replacement rate of roughly 75 percent to maintain the same standard of living in retirement. Using this rule-of-thumb, the percentage of households that would fall below this threshold is calculated for each definition of pre-retirement income (see Figure 5). While the different definitions produce replacement rates that vary somewhat widely, they all suggest a non-trivial number of older households - between 42 and 60 percent - may fall short.

\section{Conclusion}

Recent research by Bee and Mitchell (2017) has renewed concern around the accuracy of income measurements in the CPS, and some have wondered if this concern applies to retirement income estimates in other survey datasets as well. Such speculation has led some to question prior work suggesting that a large proportion of the population is ill-prepared for retirement. To address such concerns, this paper has sought to answer whether other datasets used by retirement researchers also understate retirement income.

The findings suggest that the most commonly used surveys - such as the SCF, HRS, PSID, and SIPP - provide measures of retirement income that track closely with administrative data, especially in the middle of the distribution. The SCF and HRS, in particular, tend to fit the administrative data well throughout the income distribution, while the PSID and SIPP line up closely with administrative data in all but the top quintile. Using the HRS, the replacement rate calculations suggest that between 42 and 60 percent of households are likely to fall short of a target replacement rate of 75 percent. More broadly, this paper suggests that researchers should feel comfortable using the SCF, HRS, PSID, or SIPP to draw conclusions about retirement income for the typical older household. Concerns about the CPS are well-placed, but fortunately other measures of retirement income are available and generally accurate. 


\section{References}

Bee, Adam and Joshua Mitchell. 2017. "Do Older Americans Have More Income Than We Think?" Vol. 39. SESHD Working Paper. U.S. Census Bureau: Washington, DC.

Bosworth, Barry P. and Rosanna Smart. 2009. "Evaluating Micro-Survey Estimates of Wealth and Saving." Working Paper 2009-4. Chestnut Hill, MA: Center for Retirement Research at Boston College.

Brady, Peter J., Steven Bass, Jessica Holland, and Kevin Pierce. 2017. "Using Panel Tax Data to Examine the Transition to Retirement." Available at: https://www.irs.gov/pub/irssoi/17rptransitionretirement.pdf.

Czajka, John L., and Gabrielle Denmead. 2008. "Income Data for Policy Analysis: A Comparative Assessment of Eight Surveys." Mathematica Reference 6302-601. Mathematica Policy Research: Washington, DC.

Czajka, John L., and Gabrielle Denmead. 2012. "Income Data for the $21^{\text {st }}$ Century: Updating the Current Population Survey." Final Report to the Assistant Secretary for Planning and Evaluation, US Department of Health and Human Services.

Davies, Paul, and T. Lynn Fisher. 2009. "Measurement Issues Associated with Using Survey Data Matched with Administrative Data from the Social Security Administration." Social Security Bulletin 69(2): 1-12.

Dettling, Lisa J., Sebastin J. Devlin-Foltz, Jacob Krimmel, Sarah J. Pack, and Jeffrey P. Thompson. 2015. "Comparing Micro and Macro Sources for Household Accounts in the United States: Evidence from the Survey of Consumer Finances." Finance and Economics Discussion Series 2015-086. Washington, DC: Board of Governors of the Federal Reserve System.

Dushi, Irena, Howard M. Iams, and Brad Trenkamp. 2017. "The Importance of Social Security Benefits to the Income of the Aged Population." Social Security Bulletin 77(2): 1-12.

Fisher, T. Lynn. 2008. "The Impact of Survey Choice on Measuring the Relative Importance of Social Security Benefits to the Elderly." Social Security Bulletin 67(2): 55-64.

Fox, Alan. 1979. "Earnings Replacement Rates of Retired Couples: Findings from the Retirement History Study." Social Security Bulletin 42(1): 17-39.

Fox, Alan. 1982. "Earnings Replacement Rates and Total Income: Findings from the Retirement History Study." Social Security Bulletin 45(10): 3-23.

Goss, Stephen, Michael Clingman, Alice Wade, and Karen Glenn. 2014. "Replacement Rates for Retirees: What Makes Sense for Planning and Evaluation.” Actuarial Note 155. Baltimore, MD: U.S. Social Security Administration, Office of the Chief Actuary. 
Gustman, Alan L., Thomas L. Steinmeier, and Nahid Tabatabai. 2010. Pensions in the Health and Retirement Study. Harvard University Press: Cambridge, MA.

Iams, Howard M. and Patrick J. Purcell. 2013. "The Impact of Retirement Account Distributions on Measures of Family Income." Social Security Bulletin 73 (77). Washington, DC: Social Security Administration.

Meyer, Bruce D., Wallace KC Mok, and James X. Sullivan. 2015. "Household Surveys in Crisis." Journal of Economic Perspectives 29 (4): 199-226.

Miller, Billie Jean and Sylvester J. Schieber. 2014. "Contribution of Pension and Retirement Savings to Retirement Income Security: More Than Meets the Eye." Journal of Retirement 1(3): 14-29.

Mitchell, Olivia S., and John W.R. Phillips. 2006. "Social Security Replacement Rates for Own Earnings Benchmarks." Benefits Quarterly 22(4): 37-47.

Munnell, Alicia H. and Mauricio Soto. 2005. "How Much Pre-Retirement Income Does Social Security Replace?" Issue in Brief 36. Chestnut Hill, MA: Center for Retirement Research at Boston College.

Munnell, Alicia H., and Anqi Chen. 2014. "Do Census Data Understate Retirement Income?" Issue in Brief 14-19. Chestnut Hill, MA: Center for Retirement Research at Boston College.

Purcell, Patrick J. 2012. "Income Replacement Ratios in the Health and Retirement Study." Social Security Bulletin 72 (37): 37-58. Washington, DC: Social Security Administration.

Schieber, Sylvester J. 1995. “Why Do Pension Benefits Seem So Small?” Benefits Quarterly 11(4): 57-70.

Springstead, Glenn and Andrew G. Biggs. 2008. "Alternate Measures of Replacement Rates for Social Security Benefits and Retirement Income.” Social Security Bulletin 68(2): 1-19. Washington, DC: Social Security Administration.

Woods, John R. 1996. "Pension Benefits among the Aged: Conflicting Measures, Unequal Distributions." Social Security Bulletin 59(3): 3-30. Washington, DC: Social Security Administration. 
Table 1. Aggregate Retirement Income for All Households Ages 65+, by Dataset, Billions of 2016 Dollars

\begin{tabular}{|c|c|c|c|c|c|c|c|c|}
\hline & \multicolumn{2}{|c|}{ Retirement plans } & \multicolumn{2}{|c|}{ Social Security } & \multicolumn{2}{|c|}{$\begin{array}{c}\text { Interest } \\
\text { and dividends }\end{array}$} & \multicolumn{2}{|c|}{ Total } \\
\hline & Amount & $\begin{array}{c}\% \text { of } \\
\text { admin }\end{array}$ & Amount & $\begin{array}{c}\% \text { of } \\
\text { admin }\end{array}$ & Amount & $\begin{array}{c}\% \text { of } \\
\text { admin }\end{array}$ & Amount & $\begin{array}{l}\% \text { of } \\
\text { admin }\end{array}$ \\
\hline \multicolumn{9}{|l|}{ Data from 2016} \\
\hline Administrative & $\$ 665$ & & $\$ 716$ & & $\$ 223$ & & $\$ 1,604$ & \\
\hline SCF & 660 & $99 \%$ & 678 & $95 \%$ & 236 & $106 \%$ & 1,574 & $98 \%$ \\
\hline HRS & 623 & 94 & $550 *$ & 104 & 185 & 83 & 1,358 & 96 \\
\hline CPS & 310 & 47 & 558 & 78 & 108 & 48 & 976 & 61 \\
\hline \multicolumn{9}{|l|}{ Data from 2014} \\
\hline Administrative & $\$ 611$ & & $\$ 670$ & & $\$ 220$ & & $\$ 1,480$ & \\
\hline SIPP & 594 & $97 \%$ & 663 & $99 \%$ & 133 & $60 \%$ & 1,390 & $93 \%$ \\
\hline PSID & 519 & 85 & 569 & 85 & 130 & $59 \%$ & 1,218 & 81 \\
\hline
\end{tabular}

* HRS reports Social Security income net of deductions for Medicare premiums. So the HRS is compared to the total Social Security benefits reported in the IRS 1040, which is also net of deductions for Medicare premiums. In 2016, Social Security income net of deductions for Medicare premiums was \$531 million.

Notes: Aggregates for retirement plans and interest and dividends are from IRS SOI Reports from the Form 1040. Social Security estimates are from the Annual Statistical Supplement. Capital gains and losses are excluded.

Sources: IRS SOI Table 1.5 (2014, 2016); SSA Annual Statistical Supplement (2015, 2017); CPS ASEC (2017); HRS (2016); SCF (2016) PSID (2014); and SIPP (2014). 
Figure 1a. Average Income from Social Security for Households Ages 65+ by Income Quintile for Surveys Available in 2016, 2016 Dollars

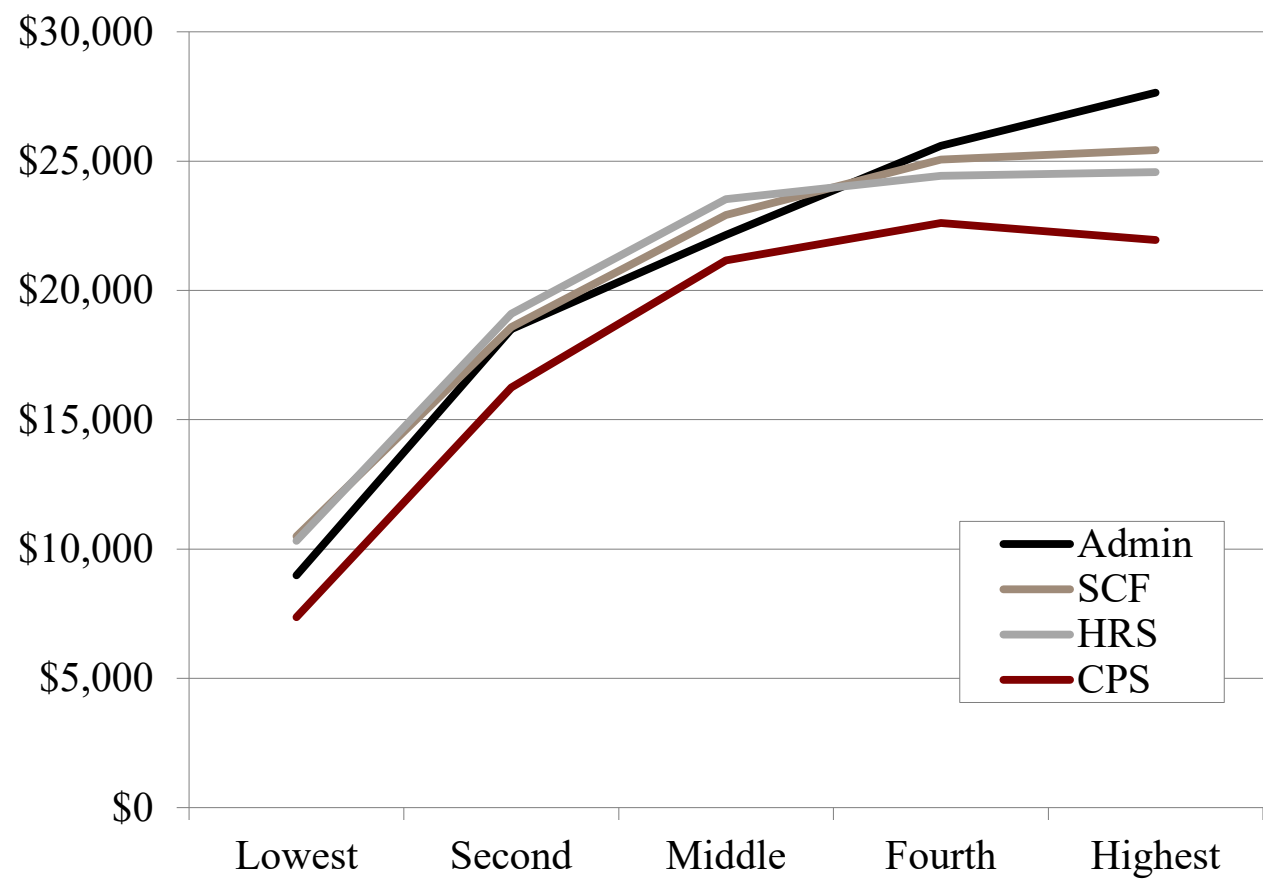

Figure 1b. Average Income from Social Security for Households Ages 65+ by Income Quintile for Surveys Available in 2014, 2016 Dollars

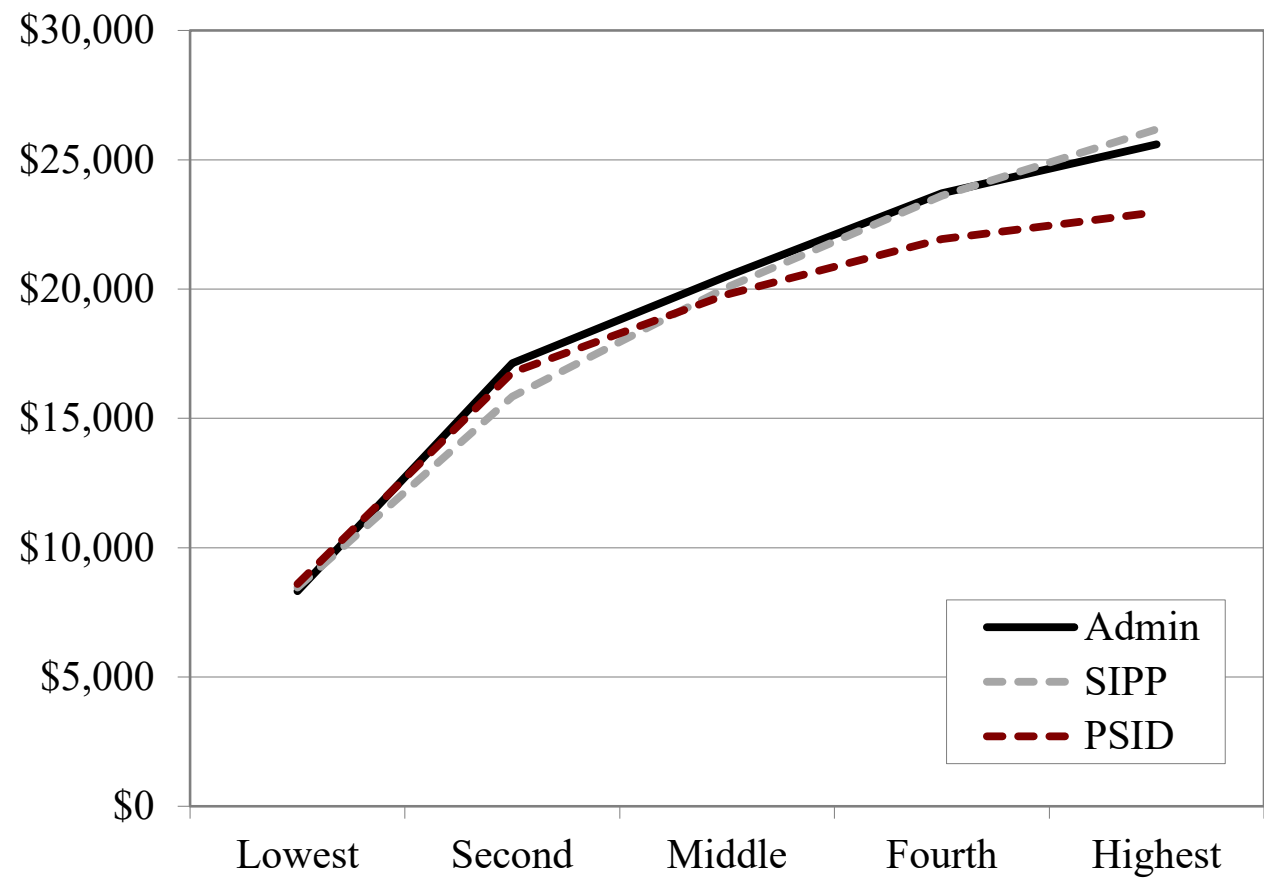

Sources: Authors' calculations from Bee and Mitchell (2017); IRS SOI (2012, 2014, 2016); SCF (2016); HRS (2016); PSID (2014); SIPP (2014); and CPS (2016). 
Figure 2a. Average Income from Retirement Plans for Households Ages 65+ by Income Quintile for Surveys Available in 2016, 2016 Dollars

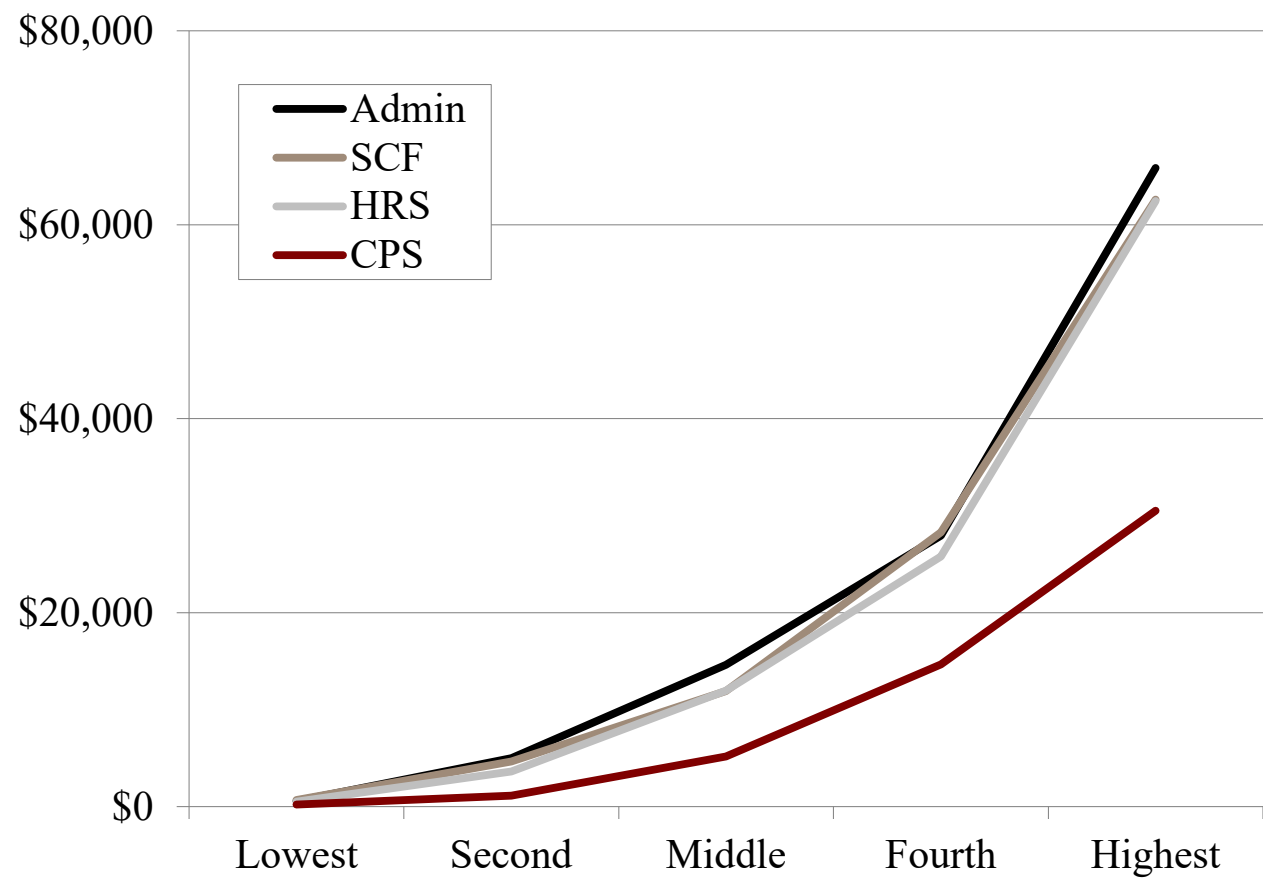

Figure 2b. Average Income from Retirement Plans for Households Ages 65+ by Income Quintile for Surveys Available in 2014, 2016 Dollars

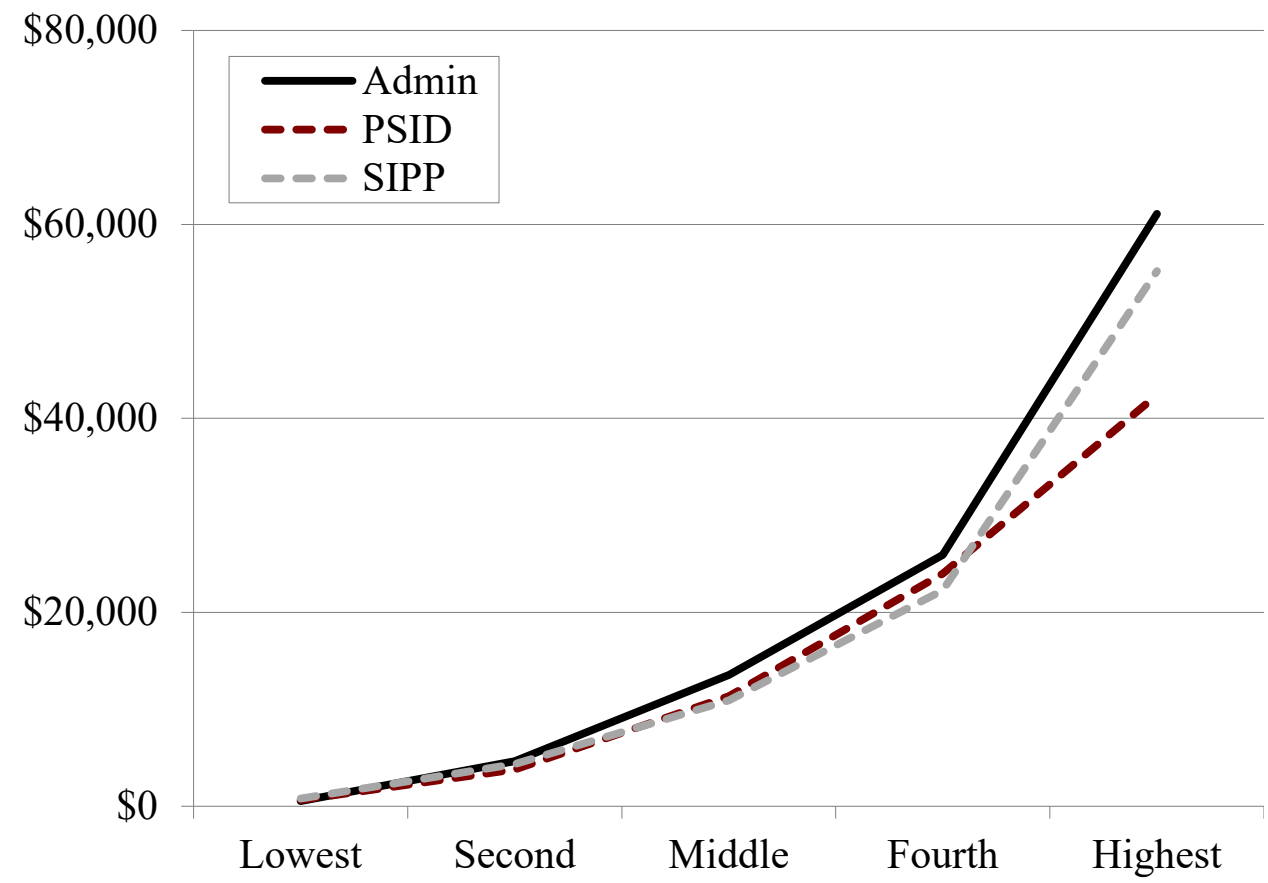

Sources: Authors' calculations from Bee and Mitchell (2017); IRS SOI (2012, 2014, 2016); SCF (2016); HRS (2016); PSID (2014); SIPP (2014); and CPS (2016). 
Figure 3. Ratio of Actual to Potential Income from Retirement Plans by Net Worth Quintile

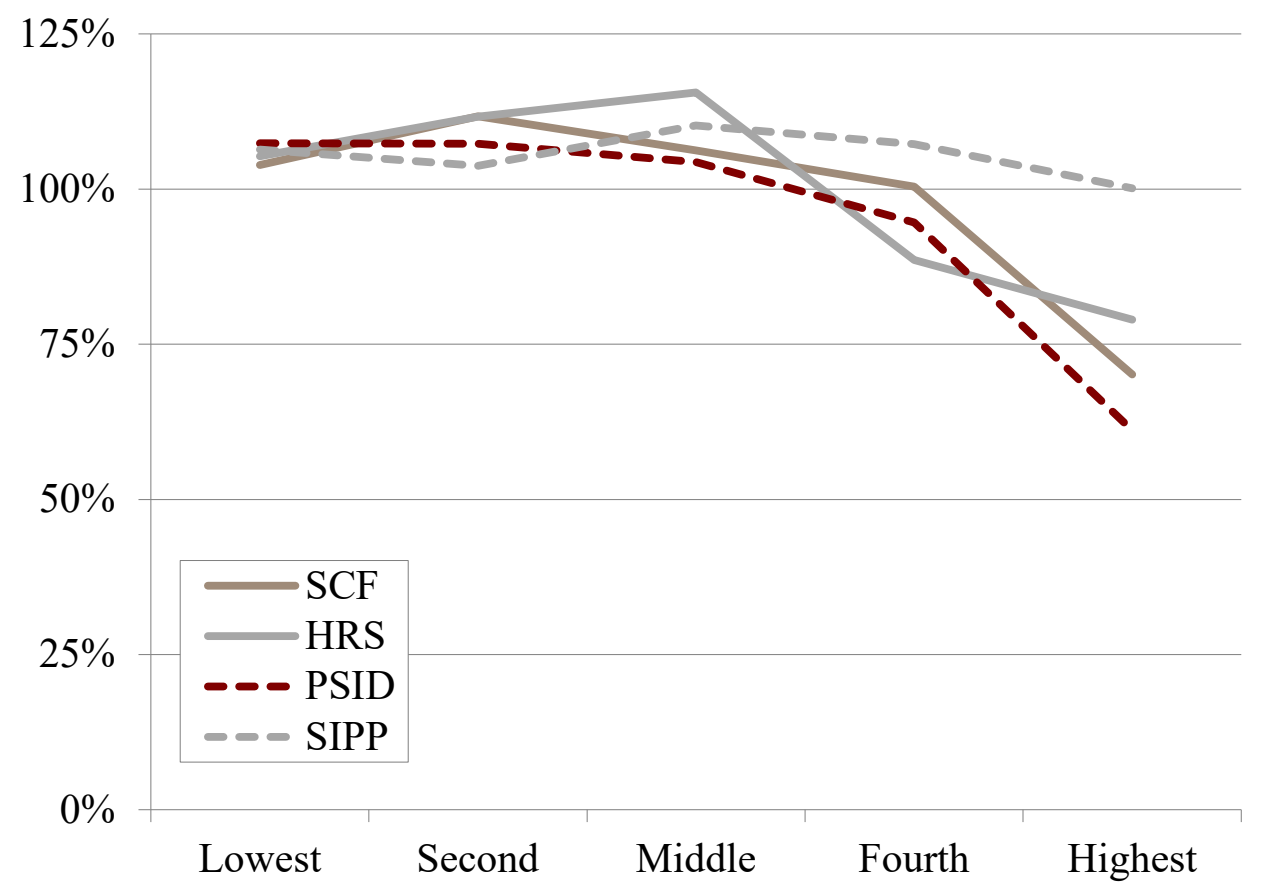

Sources: Authors' calculations from IRS SOI (2012, 2014, 2016); SCF (2016); HRS (2016); PSID (2014); SIPP (2014); and CPS (2016). 
Figure 4. Replacement Rates for Median Households Ages 65+, by Definition of Pre-retirement Income

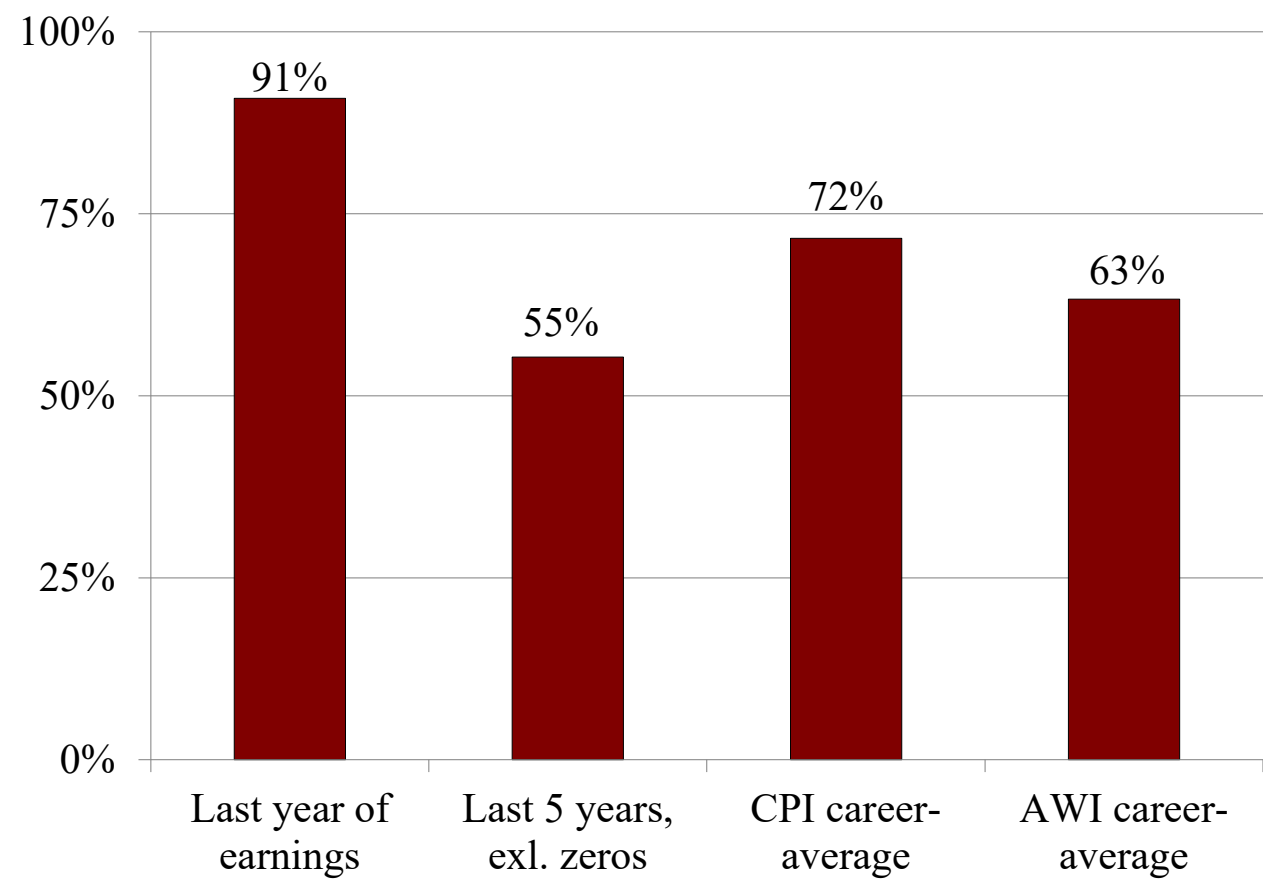

Source: Authors' calculations.

Figure 5. Percentage of Households Ages 65+ At Risk, by Definition of Pre-retirement Income

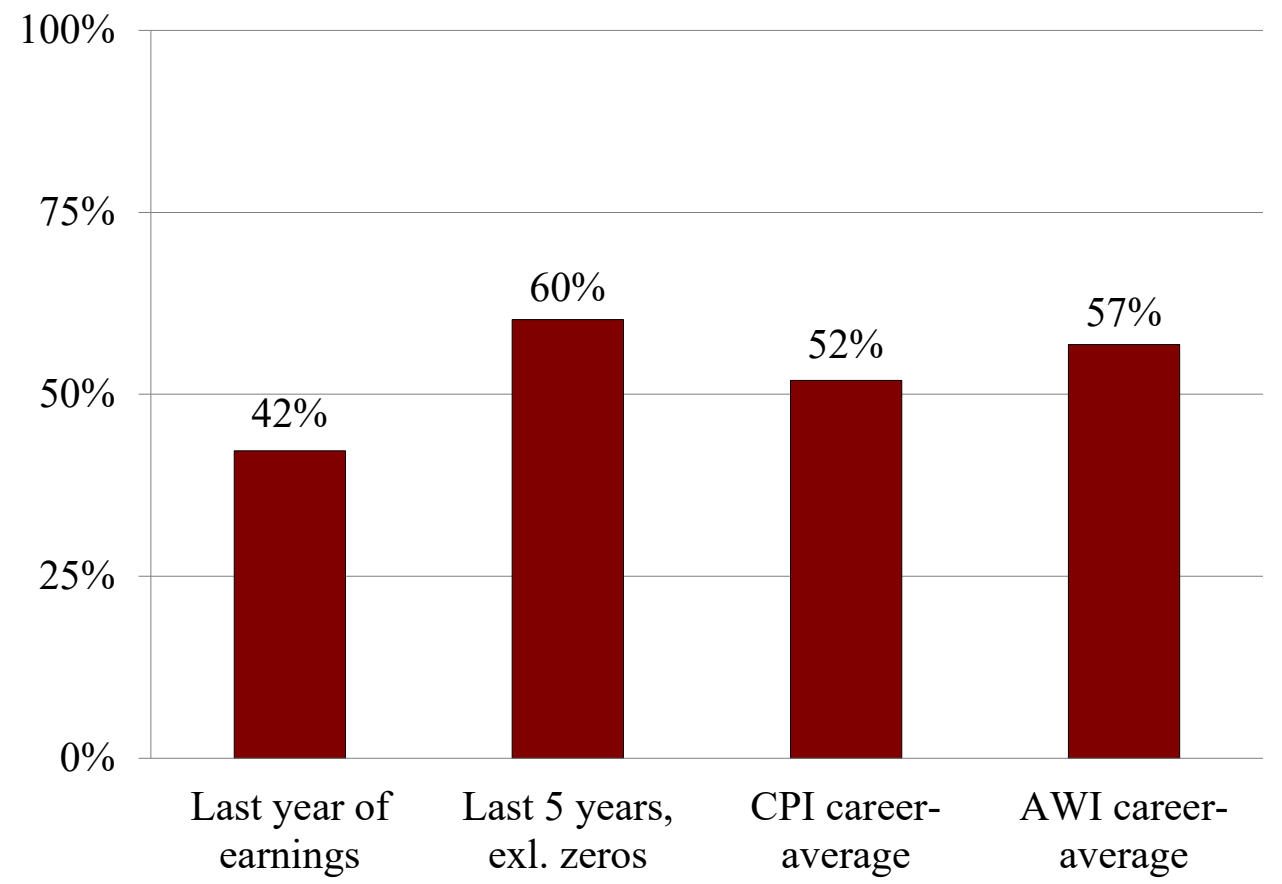

Note: Retirement income includes Social Security, retirement plans, and interest and dividends. Source: Authors' calculations. 


\section{RECENT WORKING PAPERS FROM THE CENTER FOR RETIREMENT RESEARCH AT BOSTON COLLEGE}

The Minimum Wage and Incentives for Full-Time Work Under the Social Security Retirement Earnings Test

Gary V. Engelhardt, October 2018

Would Greater Awareness of Social Security Survivor Benefits Affect Claiming Decisions? Anek Belbase and Laura D. Quinby, October 2018

How Does Delayed Retirement Affect Mortality and Health?

Alice Zulkarnain and Matthew S. Rutledge, October 2018

How Have Automation and Trade Affected the Taxable Share of Covered Earnings? Gal Wettstein, Matthew S. Rutledge, and Wenliang Hou, October 2018

Spillovers from State and Local Pensions to Social Security: Do Benefits for Uncovered Workers Meet Federal Standards?

Laura D. Quinby, Jean-Pierre Aubry, and Alicia H. Munnell, September 2018

Accounting for Social Security Claiming Behavior

Svetlana Pashchenko and Ponpoje Porapakkarm, September 2018

The Minimum Wage and Annual Earnings Inequality

Gary V. Engelhardt and Patrick J. Purcell, August 2018

Exploring the Consequences of Discrimination and Health for Retirement by Race and Ethnicity: Results from the Health and Retirement Study

Ernest Gonzales, Yeonjung Jane Lee, William V. Padula, and Lindsey Subin Jung, July 2018

Financial Management Support for SSA Beneficiaries: Looking Beyond the Payee Annie Harper, May 2018

What Factors Explain the Decline in Widows' Poverty?

Alicia H. Munnell, Geoffrey T. Sanzenbacher, and Alice Zulkarnain, May 2018

Exploring the Rise of Mortgage Borrowing among Older Americans J. Michael Collins, Erik Hembre, and Carly Urban, May 2018

How Might Earnings Patterns and Interactions Among Certain Provisions in OASDI Solvency Packages Affect Financing and Distributional Goals? Melissa M. Favreault, March 2018

All working papers are available on the Center for Retirement Research website (http://crr.bc.edu) and can be requested by e-mail (crr@bc.edu) or phone (617-552-1762). 